\title{
Water in sustainable agriculture standards
}

Dr Rachel Cooper

GSDRC, University of Birmingham

13 January 2021

\section{Question}

How does water appear in sustainable agricultural standards?

\section{Contents}

1. Summary

2. Sustainable Agriculture Standards

3. Assessment of standards

4. Integrating water stewardship and context

5. Selected examples of standards

6. References

The K4D helpdesk service provides brief summaries of current research, evidence, and lessons learned. Helpdesk reports are not rigorous or systematic reviews; they are intended to provide an introduction to the most important evidence related to a research question. They draw on a rapid deskbased review of published literature and consultation with subject specialists.

Helpdesk reports are commissioned by the UK Foreign, Commonwealth, and Development Office and other Government departments, but the views and opinions expressed do not necessarily reflect those of FCDO, the UK Government, K4D or any other contributing organisation. For further information, please contact helpdesk@k4d.info. 


\section{Summary}

Sustainable agricultural standards, hereafter standards, is a broad term encompassing certification schemes, tools, and programmes. The International Trade Centre's Sustainability Standards Map includes 166 agricultural standards ${ }^{1}$. However, there is a smaller number of prominent standards that are popularly used by major retailers or for particular commodities. Two studies looking at how water is considered in standards selected smaller numbers: Morgan (2017) benchmarks 25 popular use conventional agricultural standards and organic standards, whilst Vos \& Boelens (2014) selected eight prominent standards for their analysis.

Standards can play a role in fostering more sustainable water use but currently do not reasonably address the full range of important water issues. Traditionally many standards have restricted water criteria to efficient use and minimising both soil erosion and nutrient runoff (Morgan, 2017). Growing awareness of water risks in agricultural supply chains is one factor driving companies and standard systems' attention to water issues.

Standards' coverage of water issues varies both across and within standards. WWF's 2017 benchmarking of 25 standards against a Water Stewardship Assessment Framework using four water outcomes (quality, balance, governance and management, and important waterrelated areas) found that all standards address at least one outcome, but there is a high level of variation. Water quality is the best-covered aspect of water stewardship across the standards, followed by water balance, important water-related areas, and governance and management (Morgan, 2017).

The nature of water risks to agriculture and agricultural supply chains, and water security more broadly, require producers and retailers to look 'beyond the fence line' to catchments and other scales. Individual sites' water use can have cumulative impacts at the catchment or basin level, whilst individual sites' water use is also at risk from shared water security challenges in a catchment or basin. Standard systems could benefit from combining a focus on water use efficiency, such as irrigation efficiency, at the farm level with a consideration of cumulative water use impacts and basin thresholds (Morgan, 2017).

Water stewardship can allow a deeper understanding of context, such as catchment water security challenges and agricultural water risks. Standards can face difficulties dealing with water issues at scales beyond the farm and struggle to account for how water use is geographically and politically embedded in catchments and other scales (Vos \& Boelens, 2014). Integrating water stewardship into standards, through add-ons, training, or other mechanisms could overcome these challenges.

Other key findings include:

- The Alliance for Water Stewardship (AWS) Standard: across the small body of evidence identified for this report, the AWS Standard appears to perform well, and AWS

\footnotetext{
For more information see:

https://www.sustainabilitymap.org/standards?q=eyJzZWxIY3RIZENsaWVudCI6lk5PIEFGRkIMSUFUSU9OliwicH JvZHVjdFNIcnZpY2VzljpbeyJuYW1IljoiQWdyaWN1bHR1cmUiLCJzZWN0b3liOnRydWUsInZpc2libGUiOnRydW V9XX0\%3D
} 
is working with other standard systems such as GLOBAL G.A.P to develop trainings and add-ons to help producers engage with water stewardship. It also works with companies to assess their water risks, and with other partners on pilot projects, for example, strengthening water stewardship through landscape approaches in Indonesia.

- Global production covered by standards varies by product, but is growing. For example, only approximately $4.4 \%$ of global sugarcane production area was certified by the Bonsucro standard in 2016 (Smith et al., 2019). In contrast, by $2014,50 \%$ of coffee production was certified (IISD, 2016).

- Smallholders may be excluded from markets: certification and compliance with standards can entail relatively high resource and financial costs for smallholders.

- Critiques of standards and water: these include low levels of democracy and transparency in standard setting as may be dominated by more powerful stakeholders making it hard for smallholders to participate; and water sustainability standards set by external third parties could have consequences on the ground for indigenous and local communities' water knowledge, practices and rights.

- Common standard systems: companies using common standard systems such as GLOBAL G.A.P. and others, and mutual recognition between standards, can simplify compliance for farmers and producers if they supply multiple clients. Use of common standard systems can also act as a convenor between different stakeholders (Morgan, 2017).

The evidence base for this request was limited. Whilst water is included in individual standards, there is limited research on the efficacy or impact of standards on water issues. This review identified an extremely small number of studies that either assessed or benchmarked standards' water related requirements or the impacts of certification and water requirements on water resources. The literature is a mix of grey literature and academic, and is largely gender and disability blind.

\section{Sustainable Agriculture Standards}

Companies often use standards, such as third-party certified sustainable agriculture standards, to improve the sustainability of their procurement and supply chains, including addressing water concerns (Morgan, 2017). Agriculture is the sector most covered by Voluntary Sustainability Standards (VSS) (Lambert et al., 2020). Sustainable agriculture standards have measurable criteria to promote sustainable production outcomes with some criteria being mandatory or core requirements, whilst others are recommended. Commitments to use standards to meet sustainable procurement and sustainable supply chains have grown rapidly since 2010 (Smith et al., 2019). Standards can offer consistent and verifiable approaches that companies can use with confidence to deliver on their sustainability commitments ad achieve transparency and traceability of product origins in international trade (Morgan, 2017; Lambert et al., 2020).

A number of factors are driving the increasing uptake of standards by both companies and producers. These include consumer demand; mitigation of reputational risks for companies; industry sector pressure; and, integration of standards into public policy (Lambert et al., 2020; UNFSS, 2020). For example, the EU has included VSS in some of its free trade agreements as part of its commitment to promote fair and ethical trade schemes in its trade policies (UNFSS, 
2020). Adoption of standards can also have business benefits including efficiency gains, transparency and traceability, and improved supply chain relationships (Ugarte et al., 2017

Some standards focus on a particular commodity, whilst others can be applied to any crop or producer. There are also regional and national standards. For example, the Better Cotton Initiative and the Roundtable on Responsible Palm Oil relate to particular commodities, whereas the GLOBAL G.A.P's Integrated Farm Assurance Standard covers a range of crops. Compliance with standards can be assured in three ways: self-assurance, group assurance, and third-party audit. Prominent standards such as the GLOBAL G.A.P use third party audits.

Standards normally emerge in one of three ways (Tey et al., 2016):

- $\quad$ Civil society movements: this includes standards such as the International Federation of Organic Agriculture Movements (IFOAM), the Rainforest Alliance and Fairtrade.

- Industry-led: this includes GLOBAL G.A.P, UTZ, the 4C Association and the Ethical Tea Partnership.

- Multi-stakeholder processes: this includes commodity specific standards such as the Round Table of Responsible Soy and the Roundtable on Sustainable Palm Oil.

Whilst uptake of standards has increased, the percentage of global production certified is still limited for some crops and commodities. For example, as of 2016, roughly $4.4 \%$ of the global sugarcane production area had been certified under Bonsucro (Smith et al., 2019). Production volumes compliant with an internationally recognised standards grew at an average rate of $35 \%$ per cent per annum from 2008 to 2014 across the banana, cotton, coffee, cocoa, tea, sugar, palm oil and soybean sectors combined (IISD, 2016). IISD reviewed eight commodities and crops, estimating that by 2014 , four of the eight had compliance rates of $10 \%$ or more of global production. Coverage estimates for 2014 included Coffee- 50\%; Cocoa- 30\%; Palm oil22\%; Tea- 18\%; Bananas- 7\%; Cotton- 7\%; Cane sugar- 3\%; and, Soybeans- $2 \%$ (IISD, 2016). Crops with the highest levels of certification are heavily traded commodities, whilst coverage for staple crops such as maize, wheat and rice are lower (Tayleur et al., 2016). A 2016 review, quantifying the coverage of 12 prominent standards found that whilst the uptake of standards increased between 2000 and 2012, certified crop area only covers $1.1 \%$ of total global cropland (Tayleur et al., 2016).

Investors and national governments are also increasingly interested in standards (Smith et al., 2019). For example, the EUR 250 million investment fund, ECO. BUSINESS Fund uses compliance with voluntary sustainable standards as an eligibility criterion for loans. The UK government is working towards achieving $100 \%$ sourcing of credibly certified sustainable palm oil (Smith et al., 2019).

Some Global 500 companies such as Sainsbury's and Unilever have begun to develop inhouse supplier codes of conduct and auditing schemes (Morgan, 2017). This can create challenges for farmers who supply multiple clients (such as the costs of having to comply with multiple standards) (Morgan, 2017). It can also create challenges for collaboration between companies and with public sector agencies and civil society. Common standard systems encourage this collaboration and can act as convenor between different stakeholders, which can help to enable alignment towards common aims through dialogue (Morgan, 2017). 
The use of credible standards by businesses could contribute to achievement of the Sustainable Development Goals (SDGs) (Ugarte et al., 2017; UNFSS, 2020). Governments could play a strong role in supporting adoption through its own public procurement and trade policy (UNFSS, 2020). Public procurement represents on average $12 \%$ of GDP in OECD countries and up to $30 \%$ of GDP in developing countries (UNFSS, 2020). Ugarte et al. (2017) define credible standards systems as one that are run by an independent organisation that ensures compliance, maintains the integrity of the system and has a clear mission-driven focus on sustainability. Elements of a credible standard system include multi-stakeholder participation; transparency, independent verification and, continuous improvements (Ugarte et al., 2017). Use of standard could also be used as a basis for measuring achievement towards national targets for sustainable agricultural production (IISD, 2016).

\section{Development of the agricultural sector can be a mechanism for national economic development and poverty reduction however there are challenges for increasing} agricultural exports (Ugarte et al., 2017; Lambert et al., 2020). Agriculture is extremely important to the economies of number of developing countries including Sierra Leone $(57.4 \%$ of GDP in 2019) and Ethiopia (34\% of GDP in 2019) and to employment in developing countries (Lambert et al., 2020). Agri-food trade and consolidated supply chains have increased in recent decades, including both raw agricultural products and agro-based manufacturing exports (which extend product life or convert raw agricultural materials into more desirable commodities) (Lambert et al., 2020). Developing countries face a number of challenge in increasing agricultural exports including quality of transport and trade-related infrastructure (Lambert et al., 2020).

Smallholder farmers may be excluded from export markets because of the high financial and resource costs of achieving VVS certification and compliance with standards (Lambert et al., 2020; Vos \& Boelen, 2014). Often smallholders reach markets through the global value chain via intermediaries that may act as gatekeepers (Lambert et al., 2020). Vos \& Boelens (2014) state that some studies have shown that small farmers have difficultly complying with regulations and high certification fees. This can exclude them from producing for supermarkets. Introduction of standards in Kenya and Uganda reduced the number of smallholders exporting vegetables by half according to one 2008 study (Vos \& Boelens, 2014). Governmental intervention may be needed given the complexities and capital consuming nature of the standards and certification system (Lambert et al., 2020).

\section{Sustainable agricultural standards and water}

Water issues received little attention in standards until recently. A growing awareness of water risks in agricultural supply chains, water footprints of products, and potential negative water impacts of export agricultural has led to standards adding water control points (Vos \& Boelens, 2014; Morgan, 2017). Agriculture is responsible for $70 \%$ of global water withdrawals, which can have negative impacts in terms of water availability for other sectors and users and for water quality. Water security challenges such as scarcity could pose problems for sustainable food production, especially in a context of climate change, population growth and rising food demands. For commodities and growing regions facing high water risks, a lack of water stewardship may result in greater losses from water risks (Morgan, 2017).

Agricultural production and agricultural supply chains face a number of water risks, including but not limited to: physical risks from drought, floods, water quality, and climate 
change; regulatory risks such as weak regulation; and, reputational risks including water conflict and negative publicity (Morgan, 2017). In terms of food systems sustainability it is worth noting that approximately $51 \%$ of the UK's food is produced outside the UK including in countries with higher water stress than the UK (Green Alliance, 2018). For example, 76\% of the freshwater consumed in the supply of fresh fruit and vegetables to the UK is drawn from countries outside the UK including those that may be suffering from a high risk of water scarcity, e.g. Spain, Egypt and South Africa (Scheelbeek et al., 2020).

Irrigated export agriculture can have negative consequences for water security in growing regions and reputational risks can prompt large companies to uptake sustainable agriculture standards (Vos \& Boelens, 2014; Smith et al., 2019). For example, The Coca-Cola Company and PepsiCo have made commitments to sustainably source $100 \%$ of their sugarcane procurement via the Bonsucro Standard following concerns about the companies using excessive amounts of water to produce their products (Smith et al., 2019). Achieving the commitments from the two companies could support driving large-scale adoption of standards as The Coca-Cola Company alone buy's 5\% of the world's sugar (Smith et al., 2019).

Critiques of water in standards include (Vos \& Boelens, 2014):

- Social power relations: water sustainability standards are often set by third party external actors, this could have consequences for indigenous or local water knowledge, rights and practices, and water governance outside the direct supply chain. Standard setting by private companies could also strengthen the already strong economic and political power of leading supermarket chains and food industries with consequences for local water user communities.

- Reinforcing inequalities: standards often refer to legal compliance and adherence to national legislation as the mechanism for water rights. However, water tenure is often more complex and water rights exist in conditions of legal pluralism where official, customary and other local law systems interact. Formal water rights as a part of certification can lead to number of problems including excluding local water users who often lack formal land and water titles; legal systems tend to undermine customary water norms and organisational forms; legalising some farmers' water rights can mean that other poorer farmers become illegal water users.

\section{Assessment of standards}

Little research has been done on the direct and indirect consequences of sustainability certification on water resource use and conservation (Vos \& Boelens, 2014). An extremely small number of studies were identified during the course of this review that examine, assess or benchmark standards in relation to water issues. Writing about agricultural sustainability standards generally, Smith et al. (2019) argue that whilst up-take has increased, there is still relatively little understanding of the direct environmental benefits of largescale adoption; and the potential perverse indirect impacts of adoption. Examining the efficacy of standards is limited in academic literature (Tey et al., 2016).

A small number of studies have examined the impacts of particular standards: 
- Rainforest Alliance/SAN certified coffee farms in Colombia were more likely to use practices that reduce water use and pollution (Tayleur et al., 2016).

- In Nicaragua, Rainforest Alliance certified farms were associated with less water contamination and better water conservation (Ugarte et al., 2017). In comparison, similarly sized non-certified farms were associated with erosion around water sources.

- Rainforest Alliance certified coffee farms in Colombia had significantly higher water quality, according to indicators such as vegetation, turbidity and invertebrate species diversity.

- A review of 12 major crop standards and their role in conserving biodiversity found that water conservation is included in all them (Tayleur et al., 2016). However, the review notes that specific requirements and how they are measured and audited vary considerably between standards.

- Modelling of global compliance with the Bonsucro, the leading standard for sugarcane, estimates that global compliance with the standard could reduce irrigation water use by $65 \%$ and deliver other environmental benefits (Smith et al., 2019). Global adoption could shift production away from arid ecosystems where annual freshwater use exceeds the water use indicator; the environmental benefit of this shift is most notable in areas identified as high to severely water stressed. It could also prevent expansion into water-stressed ecosystems by increasing production on existing agricultural lands. However, displacement of other crops could drive detrimental impacts from indirect land use.

- A 2014 Better Cotton Initiative report found that participating farmers across seven countries were use less water and chemical inputs (Ugarte et al., 2017). They also had significantly higher yields and profits.

Some standards' control points for water issues are very specific, others are very broad, vaguely defined or voluntary parts of the standard (Vos \& Boelens, 2014). Their study reviewed the GLOBAL G.A.P and draft versions of the Better Cotton Initiative (BCl), BSI (Bonsucro), the Roundtable on Responsible Soy (RTRS), and the Roundtable on Sustainable Biofuels (RTSB) as well as MPS-ABC Flowers, IFOAM Organic Standard, Rainforest Alliance/SAN. Findings include:

- $\mathrm{BCl}, \mathrm{RTRS}$ and RTSB address groundwater depletion.

- The BSI does not address groundwater and sets relatively permissive standards for water pollution. This may be due to board membership, which is comprised of companies who buy sugar. This is in contrast to other standards whose boards include representatives of NGOs and research institutes.

\section{Benchmarking standards}

In 2015 and 2017, the World Wildlife Fund for Nature - Germany (WWF) benchmarked a selection of agricultural sustainability standards, scoring their coverage of a number of water issues. The two reports do not rate standards as good or bad, evaluate their water impacts or performance, or assess the broader system (e.g. governance, implementation and assurance, which can be seen as a proxy for the credibility of a scheme) but focus explicitly on standard requirements related to water (Morgan, 2017). 
The 2015 report benchmarked 21 standards and the 2017 report 25 standards. Standards selected for the 2017 report include 18 standards for conventional agriculture (e.g. Better Cotton Production, Bonsucro and the Roundtable for Sustainable Palm Oil) and 5 organic standards (e.g. China Organic Standard) $)^{2}$. Standards were selected on the basis of popular use and bolstering an understanding of organic standards and new standards developed since 2015 (Morgan, 2017).

\section{The 2017 report scores each standard on a number of water issues grouped under four water stewardship outcomes using a Water Stewardship Assessment Framework (Morgan,} 2017). Each water issue is scored from 0 (denotes no significant fulfilment of criteria, the issue may simply be mentioned in a vague way) to 3 (the issue is well covered and tied to water) (Morgan, 2017). Water issues are grouped into the following four outcomes: water governance and management (e.g. legal compliance, and water risk and context); water balance (e.g. quantitative water use information); water quality (e.g. effluent management); and important water-related areas (e.g. management of riparian, wetland and other water-related habitat areas).

The degree of coverage on water issues varied considerably across the $\mathbf{2 5}$ standards but a few standards perform consistently across the four outcomes including the Alliance for Water Stewardship (AWS) and the ISCC Plus (Morgan 2017). All of the standards address at least one or more water stewardship outcomes. However, there is a high level of variation of coverage between standards. Some standards have greater coverage or lesser coverage. For example, the Roundtable for Sustainable Biomaterials - RSB Principles \& Criteria for Sustainable Biofuel Production has greater coverage across the four outcomes than the USDA Organic standard. Across the four outcomes water balance is perhaps the most variable, for

\footnotetext{
2 The full list of standards is: AWS: Alliance for Water Stewardship - AWS International Water Stewardship Standard, v 2014; ASC: Aquaculture Stewardship Council - ASC Tilapia Standard: Version 1.0 January 2012; BCl: Better Cotton Production Principles \& Criteria, 2017 Draft, v2; BON: Bonsucro Production Standard Including Bonsucro EU Production Standard, Version 4.2 December 2016; CmiA: Cotton made in Africa - Criteria Matrix Version 3.1 - 15.02.2015; Fairtrade Standard for Hired Labour, 15.01.2014_v1.3; GCP: Global Coffee Platform - GCP_Doc_01_Baseline Common Code_v2.1_en; GGAP: Global.G.A.P. Integrated Farm Assurance All Farm Base, Crops Base, Fruit and Vegetables, English Version 5.1, July 2017; GOTS: Global Organic Textile Standard version 5.0; ISCC+: International Sustainability \& Carbon Certification - ISCC PLUS version 3.009 February 2016; LEAF: Linking Environment and Farming - LEAF Marque Standard version 14.1; PT: The ProTerra Standard - Version 3.0 - Approved Dec 28 2014; RSB: Roundtable for Sustainable Biomaterials - RSB Principles \& Criteria for Sustainable Biofuel Production, RSB-STD-01-001, Version 3.0; RSPO: Roundtable for Sustainable Palm Oil - RSPO Principles and Criteria for Sustainable Palm Oil Production 2013; RTRS: Round Table on Sustainable Soy - RTRS Standard for Responsible Soy Production Version 3.1, June 1, 2017; SAIFSA: Sustainable Agriculture Initiative - SAI Platform Farm Sustainability Assessment 2.0; SAN: Sustainable Agriculture Network - SAN-S-SP-1-V1.2 SAN Sustainable Agriculture Standard July 2017; SRP: Sustainable Rice Platform - Standard on Sustainable Rice Cultivation Version 1.0; Utz: Utz Core Code of Conduct (Version 1.1, For individual and multi-site certification, 2015) + Coffee Code of Conduct (Version 1.1); EU-O: European Organic Regulations (Plant \& Livestock - (EC) No 834/2007, 889/2008 \& 1235/2008; USDA-O: USDA Organic Standards IFOAM: International Federation of Organic Agriculture Movements - The IFOAM NORMS for Organic Production and Processing Version July 2014; NAT: Naturland Standards on Production - Version 05/2017; BIO: Bioland Standards as of November 22, 2016; OFDC-O: China Organic Standard - OFDC Organic Certification Standards, September 1, 2016
} 
example the EU Organic standard has weaker coverage of this than the RSB. There is also considerable variation within standards of coverage across the four outcomes. For example, the GOTS has reasonably strong coverage of water quality but weaker coverage of water governance.

Organic standards tend to score comparably in terms of water quality coverage but are generally weaker in terms of the other three areas when compared to conventional standards. This suggests that whilst organic standards can help to mitigate water risks associated with water quality they are not as likely to mitigate risks associated with water scarcity, weak regulations, degraded catchments or reputational risks. For Europe there is a notable difference between the public organic standard (EU Organic) and the independent organic standards such as Naturland and Bioland.

Water quality is the best-covered aspect of water stewardship across the standards, followed by water balance, important water-related areas, and governance and management (Morgan, 2017). The most strongly covered issues are: effluent management (Water Quality), water efficiency (Water Balance), legal compliance (Water Governance and Management) and management of water-related ecosystems/wetlands (Important WaterRelated Areas). Across the 18 conventional standards in Morgan's 2017 report, these elements scored a 2 or a 3 across virtually all standards, with an average score of 2.7 for water effluent management and 2.4 for the other three areas. Other elements that were well covered (average scores between 2.3 and 2.1) across the 18 standards were: adaptive water management plans, catchment impacts and ESIA (environmental and social impact assessment), qualitative water use information, water-related land cover conversion and restoration and WASH (Morgan, 2017).

Water governance issues are largely the most poorly covered (Morgan, 2017). This includes participation in water governance, indirect water use assessment, collective action, climate change resilience planning and (under Important Water-Related Areas) aquatic invasive species. This finding is similar to the 2015 report, which found that whilst effluent management, legal compliance, freshwater habitat management and WASH were reasonably well covered by many standards, collective action, action in water governance, climate change resilience, or responding to freshwater invasive species were rarely or poorly addressed (Morgan, 2017).

The ongoing lack of coverage of core water stewardship concepts suggests that whilst progress is being made, there is still room for improvement (Morgan, 2017). Supply chain (indirect) water use and water governance engagement had limited coverage in standards: only two standards and three standards scored a 2 or 3 for these aspects respectively (Morgan, 2017).

\section{Progression in standards}

WWF-Germany's benchmarking of standards found that some progress had been across standards between the 2015 assessment and the 2017 assessment (Morgan, 2017). Standards are continuously updated and between 2015 and 2017, some standard systems adopted more sophisticated criteria and started open dialogues around water (Morgan, 2017). The 2017 report found that water governance was better covered in the conventional agricultural standards, but covered of water-related areas had not substantively changed (Morgan, 2017). For example, the Better Cotton Initiative's score improved by 50\% between 2015 and 2017 
(Morgan, 2017). At the opposite end of the spectrum, the Sustainable Rice Platform's score significantly decreased as it lost many of its water-related requirements (Morgan, 2017).

\section{Integrating water stewardship and context}

There is a growing consensus that inclusion of water issues in standards must involve looking 'beyond the fence line' to the catchment, basin or landscape scale. For example, the Sustainable Agriculture Initiative argue that whilst water stewardship begins on the farm, it must extend to the surrounding landscape through a catchment approach, with stakeholder engagement being critical to success (SAI, 2013). A catchment approach to water management provides a logical and practical way to address the components of sustainability (production, society and the natural environment) in a coordinated and locally relevant context (SAI, 2013).

Standards that focus solely on farm-level water management may fail to address water risks that originate in the wider catchment (WWF \& M\&S, n.d). As such, they may not be able to address the water risks of companies operating in high water risk areas.

Standards can face difficulties in dealing with water issues in a balanced manner, especially at scales beyond the farm, and in the context of catchments (Vos \& Boelens, 2014). Standards do not necessarily account for or accommodate how water use is geographically and politically embedded in catchments, territories, and broader institutional, socio-economic and cultural contexts (Vos \& Boelens, 2014). There is limited consideration of water management and governance issues at the watershed level in standards (Vos \& Boelens, 2014). Water management is typically complex and locally specific, thus requiring specific local criteria for equitable water allocation, sustainable exploitation, resource conservation and preservation of ecosystem functions (Vos \& Boelens, 2014).

Catchment-derived risks can be addressed by incorporating water stewardship and work is ongoing to integrate water stewardship into standards ${ }^{3}$. For example, the Alliance for Water Stewardship (AWS) is working with GLOBAL G.A.P to develop an add-on that will make it easier for agricultural producers to engage with both standard systems simultaneously ${ }^{4}$. It also offers a water stewardship training programme (Morgan, 2017). A number of standards also offer water stewardship training. For example, the Sustainable Agricultural Initiative offers guidance on sustainable water management and water stewardship (Morgan, 2017). AWS and the Better Cotton Initiative have cross-trained staff on both programmes (Morgan, 2017).

\footnotetext{
3 The Alliance for Water Stewardship define water stewardship as "The use of water that is socially equitable, environmentally sustainable and economically beneficial, achieved through a stakeholder inclusive process that involves site and catchment based actions. Good water stewards understand their own water use, catchment context and shared risk in terms of water governance, water balance, water quality and important water related areas; and then engage in meaningful individual and collective actions that benefit people and nature".
}

${ }^{4}$ The partnership was announced in 2019. More information is available here: https://www.globalgap.org/uk_en/media-events/news/articles/United-in-Water-Stewardship-and-SustainablePractices/ 
For companies it is important that the use of standards matches their water risk exposure (Morgan, 2017). Morgan (2017) argues that water risk assessments may reveal that water stewardship issues covered by a certain standard do not match a company's water risk exposure. Water risks assessment should cover basin risks, operational risks and mitigation responses (Morgan, 2017). In addition to a water risk assessment, Morgan (2017) recommends that companies should accelerate sector collaboration to advance water stewardship in standards, and disclose on water stewardship in agriculture. Actions that companies can take in high water risk areas include (WWF and M\&S, n.d.):

- engaging with a range of stakeholders through participation in local forums for catchment or basin water management plans;

- provide finance for water stewardship projects;

- working with suppliers to support their involvement in collective action;

- funding the establishment of a new water stewardship partnership if one does not already exist (WWF and M\&S, n.d.).

\section{Cumulative impacts}

A focus on water use efficiency, such as irrigation efficiency, must be complemented by absolute use limits (allocations) that account for cumulative impacts and an understanding of context-driven freshwater basin thresholds (Morgan, 2017). There is an ongoing trend in standards to focus on increasing efficiency, such as irrigation efficiency (Morgan, 2017). However, this will not result in sustainable water use and could result in a Jevrons Paradox, whereby despite ever greater efficiency, the basin faces an ever increasing water scarcity challenge as improvements in irrigation efficiency reduce the amount of water returned to the natural system (Morgan, 2017). Reliance on regulatory permits has also not ensured sustainable water use to date (Morgan, 2017).

A conceptual shift is needed away from making agriculture 'less bad' (i.e. more efficient) to a contextual, systemic, basin-orientated form of agriculture that supports sustainable use of water as a common pool resource (Morgan, 2017). Water use/quality efficiency must consider cumulative impacts (Morgan, 2017). The role of companies in water governance also needs to be revisited (Morgan, 2017). Morgan (2017) argues that water stewardship begins with a deeper understanding of context and agricultural water risks. Other recommended actions are: consider collective actions and engagement in water governance; collaborate; and ensure efficiency requirements are supplemented with cumulative basin impact considerations (Morgan, 2017). The use of context-based water targets/metrics could help standards account for both efficiency gains and cumulative impacts, offering a more contextually-relevant target accounting for the status of water (scarce or abundant, polluted or clean) (Morgan, 2017).

Sustainability standards need to be evaluated within the context of the larger physical and policy landscape (Smith et al., 2019). Standards can only be effective if they complement other landscape-wide efforts (Smith et al., 2019). 


\title{
5. Selected examples of standards
}

\author{
GLOBAL G.A.P
}

More than 200,000 farms in over 135 countries have been certified by GLOBAL G.A.P (Global Good Agricultural Practice) and is an internationally recognised standard for farm production $^{5}$. The GLOBAL G.A.P system includes 155 approved certification bodies across the globe, who register and manage clients' certification data in the GLOBAL G.A.P database. Each producer and individual member of a producer group has a unique 13 digit number that is used to identify it in the database and provide instant access to registration and status data for every producer and product. Retailers and traders use the database to validate a producer's certificates.

GLOBAL G.A.P began in 1997 as EUREGAP, an initiative of the Euro-Retailer Produce Group in response to growing consumer concerns about animal and workers' welfare, environmental impact and product safety. The EUREGAP standard helped producers comply with Europe-wide accepted criteria. In 2007, it was renamed GLOBAL G.A.P to reflect the global nature of producers using the standard and its aim to become the leading G.A.P standard. It aims to have 'one auditor through the farm gate' so benchmarks a number of other standards with three different levels of recognition: equivalent scheme, approved modified checklist and resembling scheme ${ }^{6}$. Recognition and add-ons (described below) can help combat certification fatigue, and simplify things for farmers, producers and suppliers.

Over 45 retail chains (over 30 European ones, and 15 non-European ones) require proof of GLOBAL G.A.P certification from their suppliers (Flachsbarth et al., 2020). Consequently, certification is important if farmers want to access high-value markets (Flachsbarth et al., 2020). It is not limited to particular products and is gaining in relevance for many products (Flachsbarth et al., 2020). However, coverage varies among countries. Whilst this can partly be explained by the nature of global agricultural trade networks, other factors are also important including: fostering a favourable business environment through measures such as secure land tenure and a functioning judicial system, as well as investing in transportation and information infrastructure to facilitate farmers participation (Flachsbarth et al., 2020).

\section{Water in GLOBAL G.A.P}

Recognising limitations in its consideration of water issues, in 2016, it added the SPRING add-on, and it is currently working with the AWS. The SPRING (Sustainable Programme for Irrigation and Groundwater Use) was developed by the Swiss retailer Coop in 2016 as an add-on to the Integrated Farm Assurance Standard ${ }^{7}$. Producers or producer groups applying for SPRING certification must be certified against GLOBAL G.A.P Integrated Farm Assurance Standard (FiBL, n.d). It uses a range of criteria to assess sustainable water management on the

\footnotetext{
${ }^{5}$ For more information see: https://www.globalgap.org/uk_en/what-we-do/globalg.a.p.-certification/globalg.a.p./

${ }^{6}$ For more information see: https://www.globalgap.org/uk_en/what-we-do/the-gg-system/benchmarking/

${ }^{7}$ For a brief overview see https://www.globalgap.org/uk_en/for-producers/globalg.a.p.-add-on/spring/
} 
farm including: legal compliance, monitoring water consumption, impact on sustainable watershed management, best practices in water management, protection of water sources and measures to demonstrate continuous improvement of water management. The SPRING add-on certification is visible in the GLOBAL G.A.P database.

\section{Alliance for Water Stewardship standard ${ }^{8}$}

The Alliance for Water Stewardship (AWS) is a collaborative multi-stakeholder membership organisation initiated by several NGOs in 2008 to develop a water stewardship standard and certification system for sustainable water use. The standard was developed over four years through a series of global multi-stakeholder consultations and is compliant with the ISEAL standard system guidelines ${ }^{9}$. Version 2.0 of the standard was launched in 2019 following a two year review and revision process involving a number of public consultations on Version 1.0. This second version of the standard makes it easier for sites to implement and the implementation process better reflects reality on the ground.

The AWS Standard is globally-applicable and aims to drive social, environmental and economic benefits at the catchment scale. It helps major water users understand their water use, its impacts, and to work collaboratively and transparently with other stakeholders in the catchment. The standard engages water-using sites in a process of understanding and addressing both shared catchment challenges and site water risks and opportunities, addressing these challenges across five outcomes: good water governance, sustainable water balance, good water quality status, important water-related areas; and, safe WASH for all.

The standard guides users through five steps and is applicable to any site, sector or catchment. The five steps are:

- Gathering and understanding data on shared water challenges, including identifying and understanding sites' water risks;

- Development and commitment to a water stewardship plan;

- Implementation of the water stewardship plan;

- Evaluation of the water stewardship plan;

- Communicate and disclose on stewardship.

This process supports sites' to build relationships with local water-related stakeholders, and address shared challenges together. Sites are subject to third party auditing.

The standard has been implemented by Serengeti Breweries Ltd, a Tanzanian subsidiary of Diageo at its facility in Moshi (Ugarte et al., 2017). Implementation identified that the local water utility was unable to adequately manage high levels of wastewater coming through the municipality, resulting in wastewater above toxicity levels being released downstream (Ugarte et al., 2017). Serengeti Breweries Ltd collaborated with the utility and the local basin office on a

\footnotetext{
${ }^{8}$ Information taken from: https://a4ws.org/about/ \& https://a4ws.org/the-aws-standard-2-0/

${ }^{9}$ ISEAL is the global membership organisation for credible sustainability standards.
} 
pollution control programme aimed at water users in the upper part of the catchment to improve water quality for downstream users (Ugarte et al., 2017).

AWS is currently undertaking a project in Indonesia with the Roundtable on Sustainable Palm Oil (RSPO), the Global Platform for Sustainable Natural Rubber (GPSNR) and others partners to strengthen water stewardship through landscape and jurisdictional approaches $^{10}$. This 2020-2022 project will:

- develop guidance and documents on water-related indicators for the implementers of the two standards, including guidance on implementing the AWS standard;

- explore the costs, benefits and incentives for the inclusion and uptake of good water stewardship by agribusiness and governments at the landscape level;

- inform performance measurement on and monitoring of water stewardship actions at the district level in Indonesia.

\section{Bonsucro}

Bonsucro is a standard for sustainable sugarcane production. It was developed through a multi-stakeholder process informed by expert guidance and in accordance with ISEAL norms (Smith et al.,2019). The standard's water requirements focus on water quality and set a limit of fertiliser inputs, and, water use, setting a target of $90 \mathrm{~kg}$ of sugarcane per $\mathrm{mm}$ irrigation water applied. For mills, the Bonsucro standard requires a maximum consumption of $20 \mathrm{~kg}$ of water per kilo of sugar produced - though 97 per cent of certified mills consume less (Ugarte et al., 2017). Assessment of global sugarcane production found that $44 \%$ of existing production (those not signed up to the standard) is noncompliant with the water use standard devised by Bonsucro (Smith et al., 2019).

\section{The Sustainable Agricultural Network (SAN)}

The SAN is a global coalition of non-profit conservation organisations. The SAN Standard launched in 2016 includes a number of best practices and is the basis of SAN's assurance services and certification. The certification system is implemented jointly with local partners and with the Rainforest Alliance. Products grown on farms that meet the standard can use the Rainforest Alliance Certified TM seal. The SAN Standard is used for more than 100 crops over 50 countries.

\section{The Rainforest Alliance}

In 2020, it issued its new Rainforest Alliance Sustainable Agriculture Standard. This has two parts: Farm Requirements, and Supply Chain Requirements. In 2018, the Rainforest Alliance and UTZ merged, and this new 2020 standard replaces previous UTZ and Rainforest Alliance standards.

\footnotetext{
${ }^{10}$ For more information see: https://www.isealalliance.org/innovations-standards/innovations-projects/drivinggood-water-stewardship-district-level
} 
The new Farm Requirements include a number of provisions related to water, varying from core requirements, mandatory requirements and self-selected requirements. Provisions include those related to (RA, 2020):

- Riparian buffers and protection of aquatic ecosystems and drinking water sources;

- Water management and conservation including legal compliance, management and maintenance of irrigation and water distribution systems; water use for irrigation and management takes measures to reduce the use of processing water per unit of product; and self-selected improvement include rainwater harvesting for irrigation.

- Water governance: self-selected improvements including producers participating in a local watershed committee or initiative and taking action to help maintain or restore the watershed's health as part of this collective process.

- Wastewater management: core requirements to conduct tests for processing wastewater at all discharge points, and wastewater from processing operations discharged into aquatic ecosystems meets legal quality parameters; sewage water is not used for production and/or processing activities; and wastewater from processing operations cannot be applied to land unless it has undergone treatment to remove particulates and toxins. If treated wastewater is used for irrigation, in addition to the wastewater parameters, it must comply with the wastewater parameters for irrigation.

- WASH: Workers have access to sufficient and safe drinking water, sanitation and handwashing stations.

Expected outcomes from these requirements include increased efficiency in water use, and reduced wastewater (RA, 2020).

\section{Sustainable Agriculture Initiative}

The Sustainable Agriculture Initiative (SAI) Platform includes approximately 80 brands working together to support the development and implementation of sustainable agricultural practices, involving stakeholders throughout the food value chain (WWF \& M\&S, n.d.). SAI define sustainable agriculture as the efficient production of safe, high quality agricultural products, in a way that protects and improves the natural environment, the social and economic conditions of farmers, their employees and local communities, and safeguards the health and welfare of all farmed species (SAI, 2013). 


\section{References}

Flachsbarth, I., Grassnick, N. \& Brümmer, B. (2020). The uneven spread of Global G.A.P. certification. Global Food Discussion Papers, No. 137, Georg-August-Universität Göttingen, Research Training Group (RTG) No. 1666. GlobalFood, Göttingen.

http://hdl.handle.net/10419/213006

Green Alliance. (2018). Protecting standards in UK food and farming through Brexit. London: Green Alliance. https://www.greenalliance.org.uk/resources/protecting_standards_in_UK_food_and_farming_through_Brexit.pdf International Institute for Sustainable Development. (IISD). (2016). Voluntary Sustainability Standards and Biodiversity: Understanding the potential of agricultural standards for biodiversity protection. SSI Policy Brief. https://www.iisd.org/system/files/publications/voluntary-sustainabilitystandards-biodiversity-policy-brief.pdf

Lambert, S.R., Elamin, N.E.A. \& de Cordoba, S., F. (2020). Maximising sustainable agri-food supply chain opportunities to redress Covid-19 in developing countries. UNCTAD.

https://unctad.org/webflyer/maximizing-sustainable-agri-food-supply-chain-opportunities-redresscovid-19-developing

Morgan, A. J. (2017). Water risk in agricultural supply chains: How well are sustainability standards covering water stewardship - A Progress Report, WWF Germany, Berlin. https://www.wwf.de/fileadmin/fm-wwf/Publikationen-PDF/WWF-WaterRisk-Studie-EN.pdf

Rainforest Alliance [RA] (2020). Rainforest Alliance Sustainable Agriculture Standard: Farm Requirements. https://www.rainforest-alliance.org/business/wp-content/uploads/2020/06/2020Sustainable-Agriculture-Standard_Farm-Requirements_Rainforest-Alliance.pdf

Research Institute of Organic Agriculture (FiBL). (no date). Guidance to GLOBALG.A.P. SPRING assessment and certification.

https://www.globalgap.org/.content/.galleries/documents/SPRING_guide_en.pdf

SAI Platform. (2013). Water Stewardship in Sustainable Agriculture: Beyond the Farm towards a Catchment Approach. https://saiplatform.org/wp-content/uploads/2013/08/sai-platform-waterstewardship-report.pdf

Scheelbeek, P.F.D., Moss, C., Kastner, T. et al. (2020). United Kingdom's fruit and vegetable supply is increasingly dependent on imports from climate-vulnerable producing countries. Nature Food 1, pp. 705-712. https://doi.org/10.1038/s43016-020-00179-4

Smith, W.K. et al. (2019). Voluntary sustainability standards could significantly reduce detrimental impacts of global agriculture. PNAS, 5 February 2019, 116.6, pp. 2130-2137, https://www.pnas.org/cgi/doi/10.1073/pnas.1707812116

Tayleur, C. et al. (2016). Global Coverage of Agricultural Sustainability Standards, and Their Role in Conserving Biodiversity. Conservation Letters, 10.5, pp. 610-618, doi:

$10.1111 /$ conl. 12314 
Tey, Y.S., Rajendran, N., Brindal, M., et al. (2016). A Review of an International Sustainability Standard (GlobalGAP) and its Local Replica (MyGAP). Outlook on Agriculture, 45.1, pp. 67-72. doi:10.5367/oa.2016.0230

Ugarte, S., D'Hollander, D., Tregurtha, N., \& Haase, N. (2017). SDGs mean business: how credible standards can help companies deliver the 2030 agenda. Gland, Switzerland: WWF. https://www.isealalliance.org/get-involved/resources/wwfiseal-report-sdgs-mean-business-howcredible-standards-can-help-companies

United Nations Forum on Sustainability Standards. (UNFSS). (2020). Scaling up Voluntary Sustainability Standards through Sustainable Public Procurement and Trade Policy. https://unctad.org/system/files/official-document/unfss_4th_2020_en.pdf

Vos, J. and Boelens, R. (2014). Sustainability Standards and the Water Question. Development and Change, 45, pp. 205-230. https://doi.org/10.1111/dech.12083

WWF \& M\&S. (no date). The Water Stewardship Journey or Businesses: with advice from WWF and $M \& S$. https://corporate.marksandspencer.com/documents/plan-a-our-approach/mns-wwfwater-stewardship-journey-for-business.pdf

\section{Acknowledgments}

We thank the following experts who voluntarily provided suggestions for relevant literature or other advice to the author to support the preparation of this report. The content of the report does not necessarily reflect the opinions of any of the experts consulted.

- Francesca Harris, London School of Hygiene and Tropical Medicine

- Conor Linstead, WWF-UK

- Alexis Morgan, WWF Germany

\section{Suggested Citation}

Cooper, R. (2021). Water in sustainable agriculture standards. K4D Helpdesk Report 966.

Brighton, UK: Institute of Development Studies DOI: 10.19088/K4D.2021.037 


\section{About this report}

This report is based on six days of desk-based research. The K4D research helpdesk provides rapid syntheses of a selection of recent relevant literature and international expert thinking in response to specific questions relating to international development. For any enquiries, contact helpdesk@k4d.info.

K4D services are provided by a consortium of leading organisations working in international development, led by the Institute of Development Studies (IDS), with Education Development Trust, Itad, University of Leeds Nuffield Centre for International Health and Development, Liverpool School of Tropical Medicine (LSTM), University of Birmingham International Development Department (IDD) and the University of Manchester Humanitarian and Conflict Response Institute (HCRI).

This report was prepared for the UK Government's Foreign, Commonwealth and Development Office (FCDO) and its partners in support of pro-poor programmes. It is licensed for non-commercial purposes only. Except where otherwise stated, it is licensed for non-commercial purposes under the terms of the Open Government Licence v3.0. K4D cannot be held responsible for errors, omissions or any consequences arising from the use of information contained in this report. Any views and opinions expressed do not necessarily reflect those of $F C D O, K 4 D$ or any other contributing organisation.

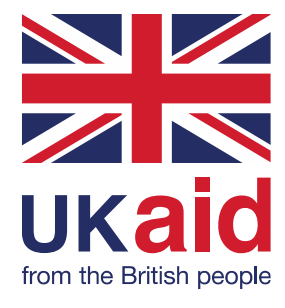

(C) Crown copyright 2021. 